\title{
Harpacticoid copepods: potential link between inbound adult salmon and outbound juvenile salmon
}

\author{
Masami Fujiwara*, Raymond C. Highsmith \\ School of Fisheries and Ocean Sciences, University of Alaska Fairbanks, Fairbanks, Alaska 99775-7220, USA
}

\begin{abstract}
Stable isotope ratios $\left(\delta^{15} \mathrm{~N}\right.$ and $\left.\delta^{13} \mathrm{C}\right)$ of estuarine organisms were measured monthly within 2 field seasons in Seldovia Bay, Alaska, USA, to assess the impact of salmon carcass decomposition on estuarine productivity. A hypothesized indirect link between adult and juvenile salmon, with estuarine harpacticoid copepods acting as an intermediary, was supported by the data. Data show an influence of nutrients derived from salmon carcasses on estuarine macroalgal primary production, as nitrogen stable isotope ratio values of Ulva sp., an estuarine macroalga, were elevated in late summer following the salmon run. The isotope data also indicate that harpacticoids depend on Ulva sp. and possibly its epiphytes. Stomach content data for chum salmon fry (Oncorhynchus keta) show that they depend primarily on harpacticoids. Therefore, there is a nutrient link between adult and juvenile chum salmon in Seldovia Bay. Because harpacticoid production in an estuary is thought to control survival of chum fry, the nutrient link may function as a positive feedback mechanism influencing population fluctuations.
\end{abstract}

KEY WORDS: Harpacticoid copepod Salmon - Seagrass - Ulva - Estuary Food web - Nutrients - Stable isotope

\section{INTRODUCTION}

Each year, large numbers of salmon spawn and die in streams along the Pacific Coasts of Asia and North America. The anadromous behavior of Pacific salmon is one of the unsolved mysteries in marine science. Why do salmon return to their natal stream? What is the advantage for them to die in the stream?

The energy and nutrients transported from the ocean by salmon can be released into aquatic environments such as streams, lakes, and estuaries through carcass decay. If the imported material is sufficient to substantially increase primary or secondary productivity of the systems, anadromous behavior of Pacific salmon can be viewed as an adaptation to provide increased food sources for their offspring. This link, which can function as a feedback mechanism between adult and juve-

\footnotetext{
- Present address: Department of Biology, Woods Hole Oceanographic Institution, Woods Hole, Massachusetts 02543.USA.E-mail:mfujiwara@whoi.edu
}

nile salmon, has been hypothesized for sockeye salmon Oncorhynchus nerka (Juday et al. 1932, Hall 1967, Kline et al. 1990), and numerous observations and experiments support the hypothesis (Eguchi et al. 1954, Nelson \& Edmondson 1955, Nelson 1959, Donaldson 1967, Krokin 1968, Barraclough \& Robinson 1972, Mathisen 1972, LeBrasseur et al. 1978, Robinson \& Barraclough 1978, Stockner 1981, Kline et al. 1993). Brickell \& Goering (1970), Sugai \& Burrell (1984), and Kline et al. (1990) have shown the strong influence of nutrients derived from adult pink salmon Oncorhynchus gorbuscha carcasses on the primary and secondary productions in stream and estuarine systems. These observations suggest the possible existence of a similar link between adults and juveniles for other Pacific salmon species

Juvenile chum and pink salmon (Oncorhynchus keta and $O$. gorbuscha), which are the focus of this study, have estuarine residence periods of up to $3 \mathrm{wk}$ and $2 \mathrm{~d}$, respectively (Neave 1966a, b, Healey 1980, 1982). Food availability in estuaries has been suggested to 
limit their survival (Parker 1965, 1968, 1971, Healey 1979, Sibert 1979, Godin 1981, D'Amours 1987). If. adult chum and pink salmon carcasses increase estuarine production, the feedback mechanism between inbound adult salmon and outgoing juvenile salmon may be a major factor in regulating populations of both species.

We hypothesized that organic carbon derived from salmon carcasses can become a seasonally important food source for harpacticoid copepods. This hypothesis was based on the following points:

(1) A large amount of dissolved organic carbon is released from adult salmon carcasses (Brickell \& Goering 1970, Sugai \& Burrell 1984).

(2) Negatively charged dissolved organic matter tends to precipitate as aggregates in an estuary where it encounters positively charged metallic ions (Morris et al. 1978).

(3) Some epibenthic harpacticoid copepods can assimilate bacterially formed aggregates of dissolved organic carbon (Rieper-Kirchner et al. 1991).

(4) Stream-transported organic matter is considered to be the major food source for the estuarine copepods when the river transport of dissolved and particulate organic matter increases (Naiman \& Sibert 1979).

(5) Harpacticoid copepods are the major food source of juvenile chum salmon (Feller \& Kazynski 1975 , Healey 1979, Sibert 1979, Landingham 1982, Cordell 1986, D'Amours 1987, Massa 1995) and juvenile pink salmon (Barnard 1981, Godin 1981, Webb 1991) during their estuarine residence periods.

Our project was designed to test this trophic-link hypothesis. In addition to testing the hypothesis, we also attempted to observe other influences of adult salmon carcasses on an estuary, such as fertilization effects on benthic algae and seagrass.

If the organic matter derived from the adult salmon carcasses actually contributes to increased spring harpacticoid copepod abundance, the anadromous behavior of chum and pink salmon may be an adaptation to increase survival rates of their offspring by nourishing prey organisms in a nursery area. This model would have important implications for the management of salmon populations.

Presently salmon harvesting is regulated so as to allow only enough females to reach nesting areas in streams (escapement) to maintain the population. 'Over-escapement' of adult salmon to a stream is thought to be deleterious to future populations mainly because the offspring would have to compete for limited resources. However, if the carcasses of adult salmon have significant positive effects on survival of offspring, optimal management plans for salmon should consider implications of this linkage.

Stable isotope ratio analysis is commonly used to reveal food web structures in terrestrial and aquatic environments (Peterson \& Fry 1987. Wada \& Hattori 1991, Michener \& Schell 1994) and is the major tool used in this project. The nitrogen stable isotope ratio, denoted by $\delta^{15} \mathrm{~N}$, of a primary producer depends on the $\delta^{15} \mathrm{~N}$ of its nitrogen sources and the origin of nutrients. The nitrogen stable isotope ratio of a consumer depends on the $\delta^{15} \mathrm{~N}$ of its food sources. At each trophic level step, $\delta^{15} \mathrm{~N}$ increases by $3.4 \%$ on average (Michener \& Schell 1994)

The carbon stable isotope ratio, denoted by $\delta^{13} \mathrm{C}$, of a marine primary producer depends on the $\delta^{13} \mathrm{C}$ values of the carbon sources and their availabilities. Values of $\delta^{13} \mathrm{C}$ are also affected by the rate of primary production, temperature, acidity, and other environmental factors. The carbon stable isotope ratio of a consumer also depends on the $\delta^{13} \mathrm{C}$ of its food sources. At each trophic-level step, little or no change is observed in $\delta^{13} \mathrm{C}$ (Michener \& Schell 1994).

Because of the predictable properties of $\delta^{13} \mathrm{C}$ and $\delta^{15} \mathrm{~N}$ in food webs, they can be used as tracers for nutrient links. Stable isotopes are especially useful in differentiating marine, terrestrial, and estuarine food sources (Peterson \& Fry 1987, Michener \& Schell 1994). Kline et al. $(1990,1993)$, for example, use this technique to trace nutrient input from salmon carcasses to a freshwater food web.

Pacific salmon $\delta^{15} \mathrm{~N}$ values (all 5 species) range between +10 and $+14 \%$ (Welch \& Parsons 1993). The $\delta^{15} \mathrm{~N}$ values of primary producers in salmon-free subarctic streams are close to $0 \%$ (Kline et al. 1990), and the values for plant tissue are also typically low (below +2\%) (Nadelhoffer \& Fry 1994). Kline et al. (1990, 1993 ) successfully used these differences between $\delta^{15} \mathrm{~N}$ of salmon and other potential nitrogen sources to quantify the influence of the salmon carcasses on freshwater primary and secondary productions.

\section{METHODS}

Study area. The study site is an intertidal estuary in Seldovia Bay $\left(59^{\circ} 23^{\prime} N, 151^{\circ} 41^{\prime} \mathrm{W}\right)$ located on the south side of Kachemak Bay, south-central Alaska, USA (Fig. 1). A small stream, the Seldovia River, flows into the bay. Pink and chum salmon (Oncorhynchus gorbuscha and $O$. keta) are the major species of salmon spawning in the river. The escapement of pink salmon into the stream was estimated to be 24400 in 1994, and the average number of the escapement over 35 yr was estimated to be about $33500 \mathrm{yr}^{-1}$ by the 
Alaska Department of Fish and Game (ADF\&G) (Bucher \& Hammarstrom 1994). The head of the bay is an intertidal delta patchily covered with seagrass Zostera marina and macroalgae Ulva sp. The river and the bay are surrounded by Sitka spruce Picea sitchensis forest. Sitka alder Alnus sinuata, paper birch Betula papyrifera, and ferns are also common vegetation. The maximum tidal range in Seldovia Bay is about $9 \mathrm{~m}$. The river freezes from late December to late February. The salinity of the sampling site (Site B) ranges from $0 \%$ during low tide to $30 \%$ at high tide.

very few people live along the stream. The town of Seldovia, where approximately 350 people live, is located $4 \mathrm{~km}$ toward the mouth of the bay from the sampling site (Fig. 1). Therefore, any anthropogenic effects on the study site are very small. The study location is close (ca $17 \mathrm{~km}$ by road) to the University of Alaska's Kasitsna Bay Laboratory.

Sampling was conducted in Seldovia Bay, 1994 to 1996. In 1996, sampling was also conducted in Jakolof Bay, Alaska, to assess variability between the 2 bays (Fig. 1). Jakolof Bay is about $10 \mathrm{~km}$ east of Seldovia Bay. Chum (Oncorhynchus keta), pink (O. gorbuscha), and silver salmon (O. kisutch) spawn in Jakolof Stream. Adult chums and pinks return to streams in Kachemak Bay from early July to early August and from July to September, respectively.

Sample collection. Sampling in Seldovia Bay was done monthly from 1994 through 1996 during late spring, summer, and early fall. In 1994, surface sediment layers, seagrass Zostera marina, and macroalgae Ulva sp. were collected from Site B (Fig. 1). In 1995, sediment cores ( $3 \mathrm{~cm}$ in diameter, $3 \mathrm{~cm}$ in depth), surface sediment layers, Z. marina, and Ulva sp. were col- lected. In 1996, the surface sediment layer from March through June), Z. Marina, and UIva sp. were collected from Site B, and macroalgae were also sampled from Site A (Fig. 1). Two locations for sediment layer collection were chosen randomly every sampling month by throwing a marker blindly within a sampling station (approximately $10 \times 10 \mathrm{~m}$ ) of nearly uniform topography. The same sampling station was used every month because the purpose of this project was to characterize time series variations rather than spatial variations. In the same manner, sites for sediment cores were chosen by throwing markers. Similarly, seagrass and macroalgae were chosen randomly by throwing a marker blindly. Only green parts of seagrass leaves were selected. Leaves of terrestrial plants (ferns, paper birch, Sitka alder, Sitka spruce), were also sampled in August 1995 and August 1996.

From May to September 1996, plankton tows were conducted monthly during high tide to collect zooplankton at Site B and at the mouth of Seldovia Bay off Outside Beach (Fig. 1). Two tows were done at each site in each sampling month to obtain 2 isotope measurements. The samples were taken to Kasitsna Bay Laboratory and filtered with 500 and $125 \mu \mathrm{m}$ mesh sieves. Plankton retained in the $125 \mu \mathrm{m}$ sieve was immediately frozen for later stable isotope ratio analysis. Zostera marina and Ulva sp. were also collected during the same period from Jakolof Bay (Fig. 1). In the same year, freshwater algae Enteromorpha sp. were also collected in Seldovia River approximately $100 \mathrm{~m}$ upstream from the extreme high tide level.

During each of the May and June sampling periods in 1995 and 1996, approximately 10 chum salmon fry were collected in a seagrass bed (Fig. 1) during low
Fig. 1. Study sites in Jakolof Bay and Seldovia Bay, Alaska, USA

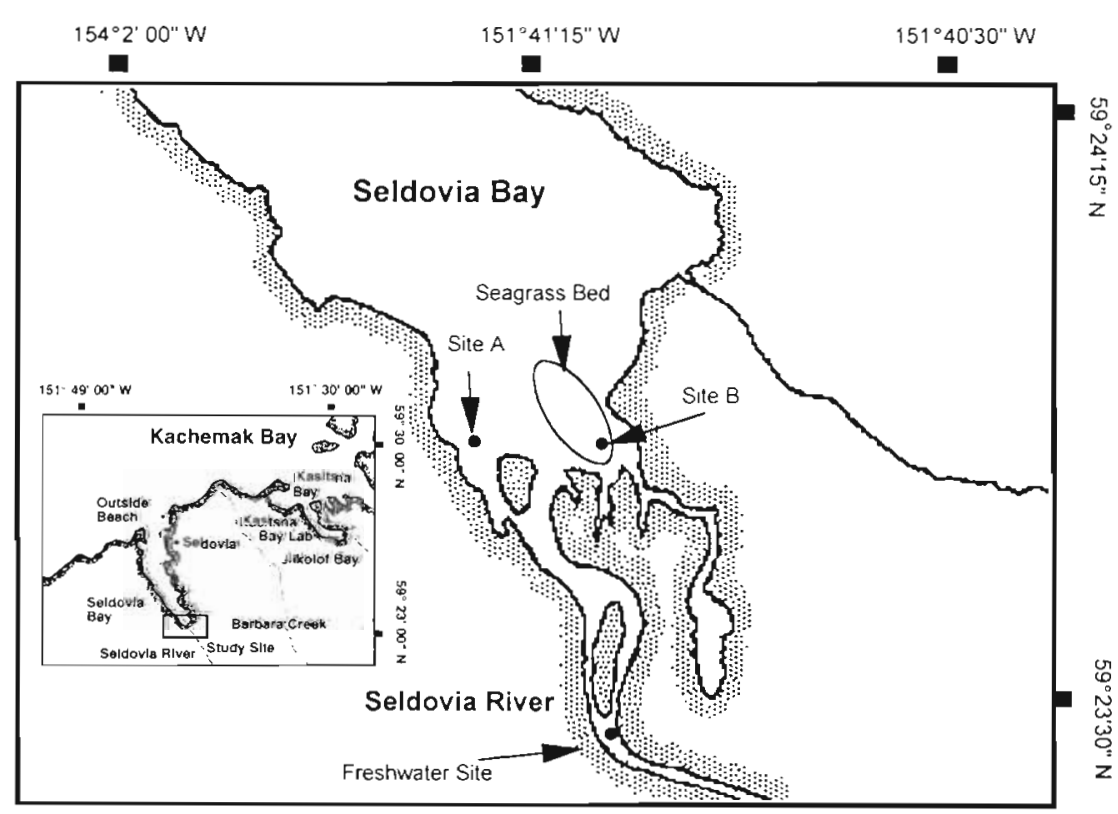


tide using a $3 \mathrm{~mm}$ mesh dip net. The fish were collected from different schools as much as possible by sampling from different locations within the seagrass bed. The captured fish were placed on a blue ice pack in a plastic bucket and transported to Kasitsna Bay Laboratory. The fish were dissected immediately. Stomachs were preserved in $10 \%$ formalin, and their contents were observed later. The rest of the body was rinsed with distilled water and frozen for later stable isotope ratio measurements.

The surface layer of the sediment was sieved through $125 \mu \mathrm{m}$ mesh, and harpacticoid copepods (mixture of several species) were separated from the detritus and sediment under a dissecting microscope. Approximately 1500 copepods were collected for each stable isotope ratio $\left(\delta^{15} \mathrm{~N}\right.$ and $\left.\delta^{13} \mathrm{C}\right)$ measurement. Phytal harpacticoid copepods (Harpacticus uniremis) were also separated from the seagrass. Because $H$. uniremis is a large species, approximately 300 individuals were sufficient for each isotope ratio measurement. This species was rarely found in sediment and was not included in the benthic copepod samples. For seagrass and macroalgae, a mixture of several leaves were used for each measurement. They were rinsed with distilled water immediately after the samples were brought to Kasitsna Bay Laboratory. After the above procedures, all samples were frozen for later stable isotope ratio measurements. In each sampling month, 2 to 3 measurements for each type of organism were done.

Adult chum $(n=2)$ and pink salmon $(n=5)$ were also sampled from Seldovia Bay and Jakolof Bay in 1995 and 1996. Muscle from the dorsal part just behind the head was used for stable isotope measurements.

Stable isotope ratio measurements. Two sediment cores from each sampling date in 1995 were thawed and rinsed through a $1 \mathrm{~mm}$ sieve, $63 \mu \mathrm{m}$ sieve, and $0.8 \mu \mathrm{m}$ Millipore filter. The material retained by the $63 \mu \mathrm{m}$ sieve and Millipore filter (scraped from the filter) was used for stable isotope ratio measurements. Both types of material contain living matter such as bacteria, Protista, and small metazoans. However, the contribution of the living matter to the stable isotope ratios of these materlals was assumed to be small, and they are called detrital material in the rest of this paper. All the other frozen samples were thawed, rinsed with distilled water, and dried in an oven overnight at $60^{\circ} \mathrm{C}$. Prior to drying the copepods, zooplankton, and detrital material, a few drops of $10 \%$ $\mathrm{HCl}$ were added to eliminate carbonate. The dried seagrass and macroalgae were ground into powder and weighed prior to analysis. Other dried samples were weighed but not ground. Lipids tend to have lower $\delta^{13} \mathrm{C}$ values than other organic molecules (Parker 1964, DeNiro \& Epstein 1977. O'Leary 1981). Our calculation, based on lipid contents of copepods measured by
Hobson \& Welch (1992) and the difference in $\delta^{13} \mathrm{C}$ values between lipid and non-lipid material measured by DeNiro \& Epstein (1977), shows that a large change in lipid contents of copepods will cause a change in $\delta^{13} \mathrm{C}$ of less than $1.4 \%$. Because this value is small for our purpose, lipid extraction from harpacticoid copepods was not done prior to isotope ratio measurements. The stable isotope ratios were determined with a continuous flow stable isotope ratio mass spectrometer ('Europa 20/20') at the Institute of Marine Science, University of Alaska Fairbanks. The determinations of stable isotope ratio values were done as described in Goering et al. (1990). $\delta^{13} \mathrm{C}$ values are reported as

$$
\delta^{13} \mathrm{C}=\frac{\left[{ }^{13} \mathrm{C}\right] /\left[{ }^{12} \mathrm{C}\right]_{\text {sample }}-\left[{ }^{13} \mathrm{C}\right] /\left[{ }^{12} \mathrm{C}\right]_{\text {standard }}}{\left[{ }^{13} \mathrm{C}\right] /\left[{ }^{12} \mathrm{C}\right]_{\text {standard }}} \times 1000 \%
$$

where standard is Peedee Belemnite (PDB limestone). Similarly, $\delta^{15} \mathrm{~N}$ values are reported as

$$
\delta^{15} \mathrm{~N}=\frac{\left[{ }^{15} \mathrm{~N}\right] /\left[{ }^{14} \mathrm{~N}\right]_{\text {sample }}-\left[{ }^{15} \mathrm{~N}\right] /\left[{ }^{14} \mathrm{~N}\right]_{\text {standard }}}{\left[{ }^{5} \mathrm{~N}\right] /\left[{ }^{14} \mathrm{~N}\right]_{\text {standard }}} \times 1000 \%
$$

where standard is atmospheric nitrogen.

\section{RESULTS}

Nitrogen stable isotope ratios of adult chum and pink salmon were $+10.62 \pm 0.02 \%( \pm \mathrm{SE})$ and $+10.90 \pm$ $0.42 \%$, respectively. These values are similar to sockeye salmon values $(+11.6 \pm 0.15 \%)( \pm \mathrm{SE})$ for the Kvichak River, Alaska (Kline et al. 1993), and to all 5 species of Pacific salmon sampled in the central North Pacific $(+10$ to $+14 \%$ ) (Welch \& Parsons 1993). The chum and pink salmon $\delta^{15} \mathrm{~N}$ values were higher than terrestrial plant, which ranged from $-2.37 \pm 0.09$ to $+0.81 \pm 0.23 \%$, indicating nutrients derived from the decomposition of salmon carcasses and plant litter would have quite distinct nitrogen isotopic signatures.

Table 1 shows carbon and nitrogen stable isotope ratios of chum salmon fry in 1995 and 1996. Their carbon stable isotope ratios differed between May

Table 1 Mean stable isotope ratios, associated standard errors, and sample sizes ( $N$ ) for chum salmon fry Oncorhynchus keta sampled in Seldovia Bay (Alaska, USA)

\begin{tabular}{|lcrr|}
\hline Date & $\delta^{13} \mathrm{C} \%$ & $\delta^{15} \mathrm{~N} \%$ & $\mathrm{~N}$ \\
\hline May 1995 & $-20.22 \pm 0.23$ & $+11.94 \pm 0.16$ & 10 \\
Jun 1995 & $-16.84 \pm 0.33$ & $+11.43 \pm 0.12$ & 14 \\
May 1996 & $-22.43 \pm 0.47$ & $+11.08 \pm 0.06$ & 5 \\
Jun 1996 & $-18.20 \pm 0.86$ & $+10.52 \pm 0.15$ & 10 \\
\hline
\end{tabular}


and June in both years, indicating their main carbon sources were probably different between the 2 months.

Concordance of temporal changes in mean stable isotope ratios of benthic harpacticoid copepods, UIVa sp., and seagrass in 1995 and 1996 was analyzed by pairwise comparisons of differences in monthly mean stable isotope ratios (i.e. benthic harpacticoids vs Ulva $\mathrm{sp}$. and benthic harpacticoids vs seagrass). These analyses were done with Bonferroni multiple comparison tests and by constructing Bonferroni $95 \%$ confidence intervals consisting of 13 intervals. Standard deviations of stable isotope ratio values were assumed to be constant for the duration of the study. The results of the tests show that there were no significant differences over time among the monthly differences between the stable isotope ratios (both $\delta^{13} \mathrm{C}$ and $\delta^{15} \mathrm{~N}$ ) of macroalgae and harpacticoid copepods in 1995 ( $p>$ $0.05)$, indicating trends in mean stable isotope ratios for the 2 organisms remained the same (Fig. 2). However, the differences between harpacticoid and Zostera marina values changed between months in 1995 ( $\mathrm{p}<0.05)$, indicating trends in mean stable isotope ratios for the 2 organisms varied independently over time (Fig. 2).

The differences in stable isotope ratios (both $\delta^{13} \mathrm{C}$ and $\delta^{15} \mathrm{~N}$ ) between benthic harpacticoid copepods and Ulva sp. did not change $(\alpha=0.05)$ in 1996 except for $\delta^{15} \mathrm{~N}$ in May (Fig. 3). The 2 harpacticoid $\delta^{15} \mathrm{~N}$ measurements in May differed considerably (difference of $1.75 \%$ ), suggesting a possible outlier. If the higher value is eliminated, the difference in mean harpacticoid and macroalgae $\delta^{15} \mathrm{~N}$ values in May would be within the confidence intervals for other months. We conclude that trends in monthly mean stable isotope ratios of harpacticoid copepods and UIva sp. were the same over $2 \mathrm{yr}$, suggesting a trophic relationship between them.

Peterson \& Fry (1987) reported that carbon stable isotope ratios generally increase between 0.0 and $+1.0 \%$ per trophic level. Michener \& Schell (1994) found a similar range of +0.5 to $+1.0 \%$ for ${ }^{13} \mathrm{C}$ enrichment per trophic level. Nitrogen stable isotope ratios show a mean increase of $+3.4 \%$ per trophic level on average (Michener \& Schell 1994). All monthly confidence intervals for differences between harpacticoid and Ulva sp. $\delta^{13} \mathrm{C}$ values overlap with the conservative 0.0 to $+1.0 \%$ range; however, the confidence intervals for harpacticoids and seagrass do not always overlap with the expected range and would not even if the range was extended to -1.5 to $+1.5 \%$. Furthermore, all monthly confidence intervals for differences between harpacticoid copepod and Ulva sp. $\delta^{15} \mathrm{~N}$ values overlap with the $+3.4 \pm 1.0 \%$ range. However, the values for harpacticoids and seagrass do not always overlap with
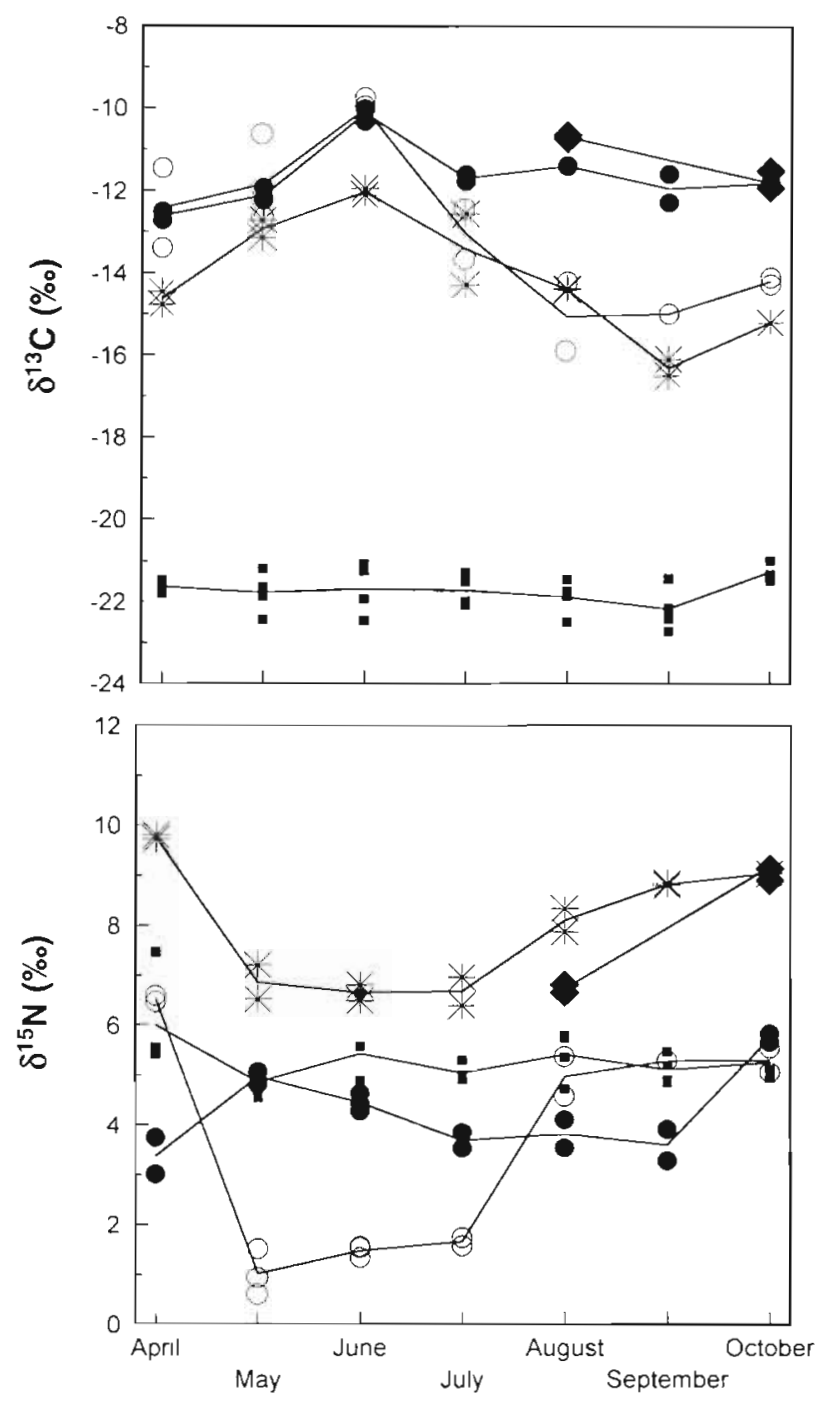

Fig. 2. Carbon and nitrogen stable isotope ratios of (O) estuarine macroalgae Ulva sp., (-) seagrass Zostera marina, (-) detritus, (*) benthic harpacticoid copepods, and $(\$)$ Harpacticus uniremis in 1995 . Lines connect monthly mean values of each type of organism

the range. Therefore, the limited magnitude of the differences between the stable carbon isotope ratios of benthic harpacticoid copepods and Ulva sp. also supports a trophic relationship between the 2 organisms.

Nitrogen stable isotope ratios of Ulva sp. collected at Site B in 1996 showed a similar trend (low values during the summer months and high values during spring and fall) to samples collected in 1995 (Fig. 3). Furthermore, similar trends were also observed among Ulva sp. collected at Site A (different location in Seldovia Bay) and in Jakolof Bay (Fig. 4). Compared with UIva sp., seagrass did not show large monthly changes in $\delta^{15} \mathrm{~N}$ (Fig, 4).

The results of the 2 -factor ANOVA (month and size factors) indicate that the $\delta^{13} \mathrm{C}$ values of detrital mater- 



Fig. 3. Carbon and nitrogen stable isotope ratios of $(0)$ estuarine macroalgae Ulva sp., $\bullet$ freshwater algae Enteromorpha sp., (-) seagrass Zostera marina, (*) benthic harpacticoid copepods, and ( $\boldsymbol{0})$ phytal harpacticoid copepods in 1996. Lines connect monthly mean values of each type of organism

ial did not differ significantly among months (2-factor ANOVA: $\mathrm{p}=0.157$ ). Furthermore, $\delta^{13} \mathrm{C}$ values of detrital material did not differ between the 2 size fractions (2-sample t-test: $\mathrm{p}=0.280$ ). Nitrogen stable isotope ratios of detrital material also did not differ significantly among months or between the 2 size fractions (2-factor ANOVA: $p=0.185, p=0.213$ ).

$\delta^{13} \mathrm{C}$ values of zooplankton, primarily calanoid copepods, at Site B in Seldovia Bay ranged from -18.39 \pm $0.30 \%$ in March to $-21.16 \pm 0.30 \%$ in June and August in 1996 . These values are different from seagrass values, which ranged from $-9.12 \pm 0.17$ to $-14.13 \pm 0.17 \%$, and Ulva sp. values, which ranged from $-10.95 \pm 0.84$ to $-15.71 \pm 0.84 \%$ in 1996 (Fig. 5).

Data for 1995 and 1996 stable isotope ratios were pooled, and the $\delta^{15} \mathrm{~N}$ values of groups were plotted against their $\delta^{13} \mathrm{C}$ values (Fig. 5). Estuarine, marine, and terrestrial production can be clearly distinguished. Pairwise comparisons of isotope ratios for estuarine

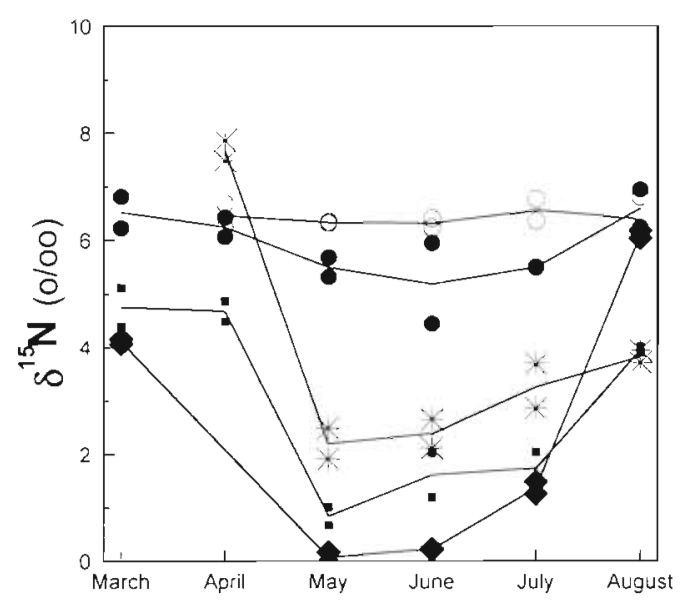

Fig. 4. Monthly mean nitrogen stable isotope ratios of macroalgae Ulva sp. ( $(*$ = Jakolof Bay, $\bullet$ Site A, $\boldsymbol{\|}=$ Site B) and seagrass Zostera marina $(\mathrm{O}=$ Jakolof Bay, $\bullet=$ Site $\mathrm{B})$ in 1996

(seagrass and Ulva sp.), marine (zooplankton), and terrestrial (alder, birch, fern, marsh grass, and spruce) organisms were done. Marine and terrestrial (2-sample t-test: $\mathrm{p}=0.00$ ), estuarine and marine (2-sample $t$-test: $\mathrm{p}=0.00$ ), and estuarine and terrestrial (2-sample $t$-test: $\mathrm{p}=0.00$ ) organisms had significantly different $\delta^{13} \mathrm{C}$ values.

Stomach contents of chum salmon fry are shown in Figs. $6 \& 7$. In both years, the fry depended primarily on harpacticoid copepods (Fig. 6). Among the harpacticoid copepods, Harpacticus uniremis was the most abundant species by number in the stomachs (Fig. 7).

\section{DISCUSSION}

\section{Nutrient sources for primary producers}

Nitrogen stable isotope ratios of major terrestrial plants (alder, birch, and spruce) observed in this study ranged from $-2.37 \pm 0.09( \pm \mathrm{SE})$ to $+0.81 \pm 0.23 \%$. A value close to or lower than $+1 \%$ often indicates that there is a large contribution of nutrients originating from nitrogen fixation (Gu \& Alexander 1993). Alder has symbiotic nitrogen-fixing bacteria, so its nitrogen isotope ratio is usually close to atmospheric values $\left(\delta^{15} \mathrm{~N}=0 \%\right)$ (Gu \& Alexander 1993). Plants with deeper rooting systems, such as spruce and birch, in the subarctic and arctic can also have low $\delta^{15} \mathrm{~N}$ relative to other plants because they access nutrients in deeper soil where nutrient nitrogen has a lower $\delta^{15} \mathrm{~N}$ (Gu \& Alexander 1993, Nadelhoffer \& Fry 1994). Because all 3 major plants around Seldovia Bay have low $\delta^{15} \mathrm{~N}$ values, terrestrially derived nutrient nitrogen is also expected to have a very low $\delta^{15} \mathrm{~N}$. 

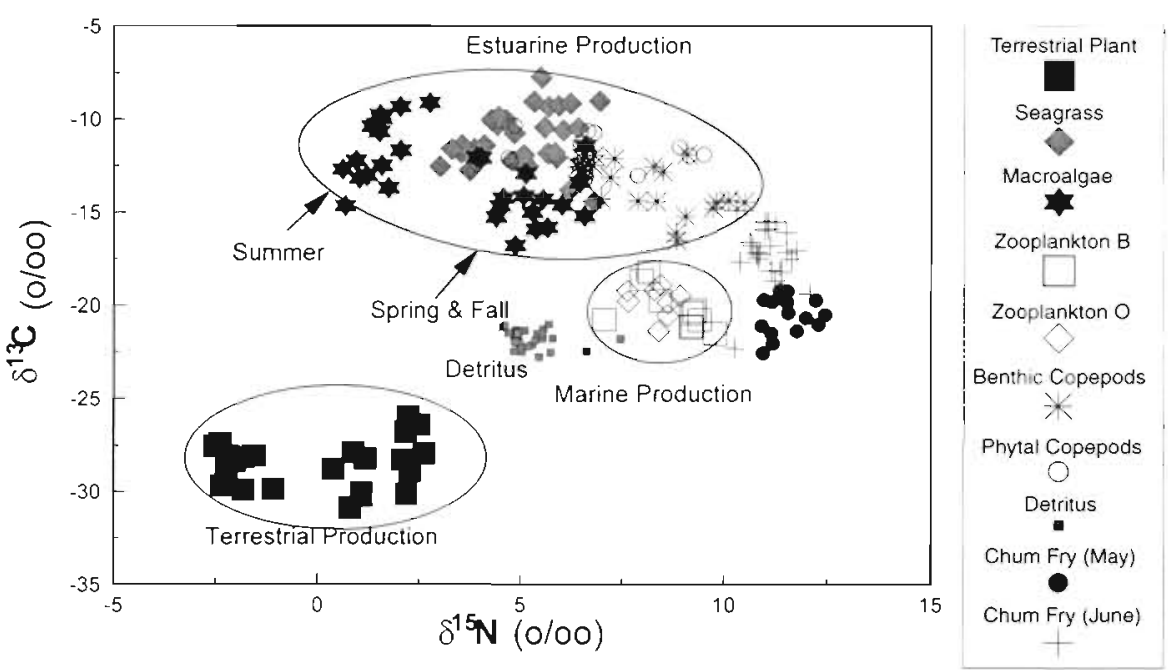

Fig. 5. Pooled carbon and nitrogen stable isotope ratios of benthic copepods, phytal copepods, detritus, macroalgae, seagrass, terrestrial plants (alder, birch, spruce, and marshgrass), and zooplankton (B = Site B, O = Outside Beach) in 1995 and 1996. Circles show data clusters for estuarine, marine, and terrestrial organisms

Nitrogen stable isotope ratios of Ulva sp. changed seasonally. Ulva sp. absorbs nutrients from the surrounding water in which the isotopic values of the dissolved nitrogen can change depending on its form (i.e. nitrate, nitrite, and ammonium) and source (i.e. recycled, terrestrial, or marine). During summer months (May, June, and July), $\delta^{15} \mathrm{~N}$ values of Ulva sp. were low $(+1.38 \pm 0.19 \%$ in 1995 and $+1.40 \pm 0.18 \%$ in 1996$)$, indicating a possible contribution of nutrients originating from nitrogen fixation. There is no report of Ulva sp. having nitrogen-fixing capabilities or associated symbionts with nitrogen-fixing capability. Therefore, the low $\delta^{15} \mathrm{~N}$ values suggest an input of nutrient nitrogen with a low $\delta^{15} \mathrm{~N}$ to the study site. The nitrogen stable isotope ratio of Enteromorpha sp. sampled in the Seldovia River in June was also low $(+0.78 \pm 0.28 \%)$ and, as with Ulva sp., increased in summer (Fig. 3). This suggests that nutrients utilized by Enteromorpha $\mathrm{sp}$. and Ulva sp. during the summer months came primarily from an upstream source. Nitrogen from sewage can have a low $\delta^{15} \mathrm{~N}$ (Rau et al. 1981). However, very few people live in the area near the stream so sewage cannot be a major nutrient source. Nutrient nitrogen with low $\delta^{15} \mathrm{~N}$ (near $0 \%$ ) can be derived from nitrogen-fixing bacteria or decomposition of terrestrial plant material in soil. We were unable to distinguish between these potential sources, but decomposition of plants definitely occurs at least seasonally in the area.

On the other hand, the increased $\delta^{15} \mathrm{~N}$ values of Ulva sp. observed after July in 1994, 1995, and 1996 were likely due to nutrients derived from salmon tissues, which have high $\delta^{15} \mathrm{~N}$ values, $+10.62 \pm 0.02$ and +10.90 $\pm 0.42 \%$ for chum and pink salmon, respectively. This conclusion is based on the following 5 points. (1) The increase in $\delta^{15} \mathrm{~N}$, which occurred in August in both 1995 and 1996, closely followed the adult salmon run, which began in early July and continued through September. (2) All other major nitrogen sources above the estuary (spruce, alder, birch, and nitrogen-fixing bacteria) have very low $\delta^{15} \mathrm{~N}$ values $(-2$ to $+2 \%$ ). (3) A high standing stock of Enteromorpha sp. and Ulva sp. appeared in the stream and the bay from late July to August (authors' pers. obs.), indicating that extra nutrients probably became available around this time.
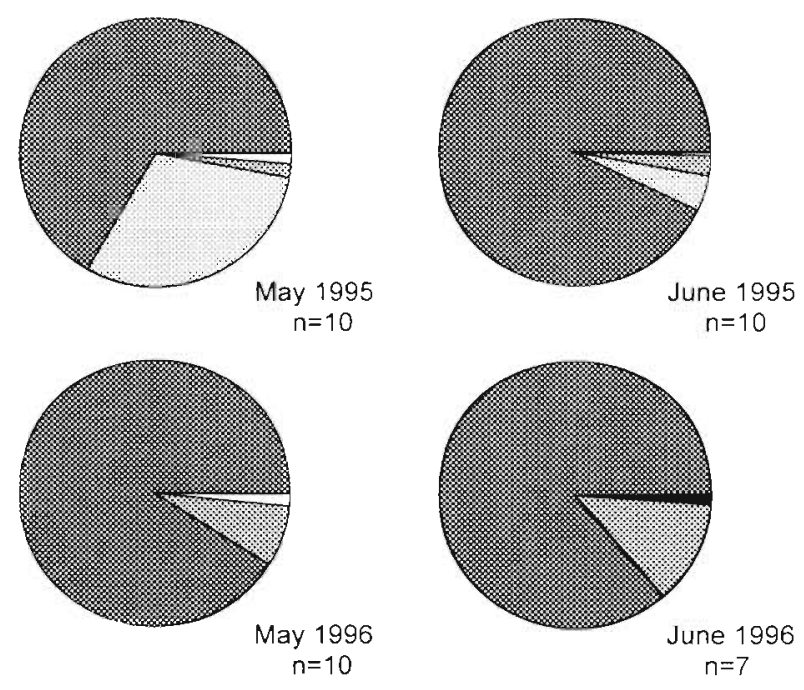

Brarpacticorda 口insecta

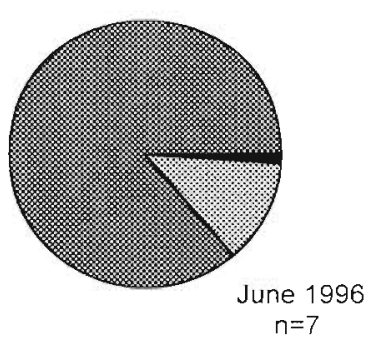
BCyclopoida
- Calanoida

B Amphipoda

Fig. 6. Relative proportion by number of total invertebrates found in the stomachs of chum salmon fry (Oncorhynchus keta) in Seldovia Bay 


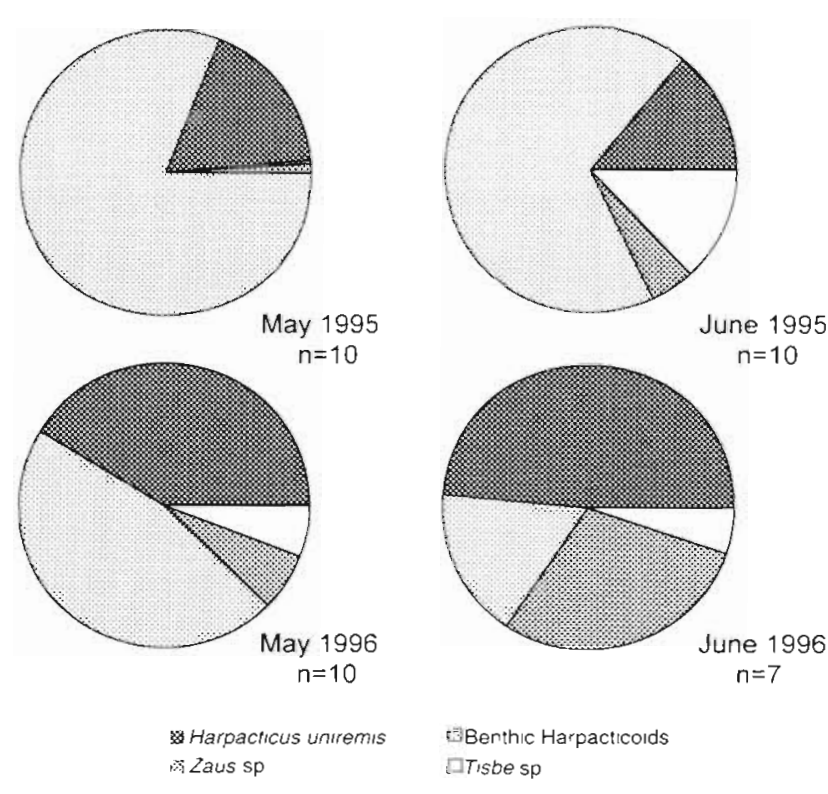

Fig. 7 Relative proportion by number of harpacticold copepod species found in the stomachs of chum salmon fry (Oncorhynchus keta) in Seldovid Bay

(4) Precipitation, which is often correlated with decomposition rates of terrestrial organic matenal, is at a minimum during the summer months in this area (Watson et al. 1971). (5) Zooplankton collected at Site B and Outside Beach did not show a signuficant monthly change in $\delta^{15} \mathrm{~N}$ between June, July, and August samples (single-factor ANOVA. $p=0.16, p=0.17$ ), indlcating that phytoplankton $\delta^{15} \mathrm{~N}$ values did not change significantly dunng the summer months.

A high $\delta^{15} \mathrm{~N}$ for Ulva sp. was found in April 1995 and again in March and April 1996. Furthermore, $\delta^{15} \mathrm{~N}$ values of Ulva sp. were also high in February 1997 1+6.92 $\pm 0.28 \%$ on Seldovia Bay, $+7.07 \pm 0.42 \%$ in Jakolof Bay), indicating that Ulva sp. collected in spring was likely produced in the previous fall. Therefore, the nutrient nitrogen derived from salmon carcasses could have a strong influence on the organisms at the study site from fall to early spring

Ulva sp. collected from Site A and Jakolof Bay in 1996 also showed low $\delta^{15} \mathrm{~N}$ during the summer $(+0.56 \pm$ 0.41 and $+2.61 \pm 0.32 \%$ ) and high $\delta^{15} \mathrm{~N}$ in spring and fall $(+5.11 \pm 0.81$ and $+5.75 \pm 1.56 \%$ o). Therefore, the trend found at Site B is a spatially and temporally general phenomenon for the study region.

Compared with Ulva sp., seagrasses did not show large monthly changes in $\delta^{15} \mathrm{~N}$, indicating they probably had different nitrogen sources. Seagrass can absorb nutrients through leaves and roots (Izumi \& Hatton 1982, Short \& McRoy 1984, Pederson \& Borum 1993) and also recycle nutrients internally (Pederson \& Borum 1993). The difference in the trends between
Ulva sp and seagrass isotope ratios suggests the seagrass at the study site primarily utilized nitrogen from the sediment and internal recycling.

\section{Estuarine detrital material}

The carbon stable isotope ratio value of detritus, which ranged from $-22.43 \pm 0.31 \%$ o $( \pm \mathrm{SE})$ to $-21.17 \pm$ $0.31 \%$, was more negative than those of macroalgae, which ranged from $-15.07 \pm 0.84 \%$ to $-10.03 \pm 0.68 \%$, and seagrass, which ranged from $-12.62 \pm 0.17$ to $-10.14 \pm 0.14 \%$ (Fig. 2). Because bacterial decomposition causes small or no changes in $\delta^{13} \mathrm{C}$ (Coffin et al. 1989, 1990), the data suggest that detrital carbon was mostly allochthonous with a possible small contribution of autochthonous material.

The data do not, however, show whether the allochthonous material is of freshwater, marine, or terrestrial ongin because they all have more depleted $\delta^{13} \mathrm{C}$ values than autochthonous material. Most identifiable detrital material (i.e. large material) found in the Seldovia River estuary was terrestrial plant parts (authors' pers. obs.). However, the maximum tidal range in Seldovia Bay is large, reaching $9 \mathrm{~m}$ during spring tides, and large volumes of water over the intertıdal estuary are exchanged with Kachemak Bay. Therefore, phytoplankton can also be a potential source of detrital material at the study site.

\section{Food sources for harpacticoid copepods}

Carbon stable isotope ratios of benthic and epiphytic harpacticold copepods Harpacticus uniremis ranged from $-16.31 \pm 0.28$ to $-12.04 \pm 0.28 \%$ and from $-11.80 \pm$ 0.33 to $-10.70 \pm 0.40 \%$, respectively, in 1995. Similarly, they ranged trom $-14.41 \pm 0.28$ to $-12.01 \pm 0.28 \%$ and from $-13.04 \pm 0.57$ to $-10.37 \pm 0.57 \%$, respectively, in 1996. They were more enriched in $\delta^{13} \mathrm{C}$ than freshwater algae $(-16$ to $-24 \%$ ), terrestrial and marsh plants (around $-29 \%$ ), and zooplankton (around $-20 \%$ ). Seagrass and estuarne macroalgae were enriched in $\delta^{1.3} \mathrm{C}$ and avalable as a food source in the estuary. Therefore, we conclude that both types of harpacticoid copepods primanly fed on these materials.

Trends in monthly means of $\delta^{13} \mathrm{C}$ and $\delta^{15} \mathrm{~N}$ for benthic harpacticold copepods and Ulva sp. are very similar to each other However, trends in monthly means of $\delta{ }^{13} \mathrm{C}$ and $\delta^{15} \mathrm{~N}$ for benthic harpacticoid copepods and seagrass are different (see 'Results'). These results suggest that Ulva sp. is a potential food source, but seagrass is not a major food source for harpacticoid copepods Ulva sp. and Zostera marina were the only noticeable vegetation at the sampling site in 1995 and 
1996, and Ulva sp. has been experimentally shown to be a good food source for some harpacticoid copepods (Miliou \& Moraïtou-Apostolopoulou 1991). Therefore, a likely explanation of the data is that the harpacticoid copepods depended primarily on UIVa sp. and possibly associated epiphytes, which were not measured but presumed to have similar isotopic signatures to Ulva $\mathrm{sp}$. because the epiphytes are exposed to the same carbon and nitrogen sources.

Alternative interpretations of the data, however, are possible. Unobserved material could have become seasonally available to harpacticoid copepods and their diet composition changed during this study, causing the observed changes in stable isotope ratios. If this is the case, seagrass could be contributing to the diet of benthic harpacticoid copepods and the seasonal trend of seagrass isotopic signature was masked by the changes in their diet composition. However, for this scenario to be true, the similarity of the seasonal trends between harpacticoid copepods and Ulva sp. must be dismissed as a mere coincidence. Another possible interpretation of the data is that unobserved material with a similar isotopic signature to Ulva sp. was actually the primary food source for the benthic harpacticoids. Benthic microalgae such as diatoms are one type of such potential food material. Schwinghamer et al. (1983) measured $\delta^{13} \mathrm{C}$ of Ulva sp. and benthic diatoms in the Bay of Fundy. Their data show that benthic diatoms are more depleted in $\delta^{13} \mathrm{C}$ than Ulva sp. Stable isotope ratios of benthic microalgae were not measured in this study, so they cannot be excluded entirely as a potential food source for harpacticoid copepods. However, among the conceivable explanations, benthic harpacticoid copepod utilization of Ulva sp. and associated epiphytes seems the most parsimonious interpretation of the data

Harpacticus uniremis appeared to feed on autochthonous material in the Seldovia Bay estuary, but we were unable to determine the source. Hall \& Bell (1993) showed that Harpacticus sp. found in a seagrass bed at Egmant Key, Florida, USA, fed on algal epiphytes on seagrass blades. Large numbers of diatom colonies became noticeable in the seagrass bed in Seldovia Bay in 1996 and may have been utilized to some extent by $H$, uniremis. In this study, $\delta^{15} \mathrm{~N}$ values of seagrass and $H$. uniremis are very similar. If $H$. uniremis primarily fed on seagrass, it should be more enriched in ${ }^{15} \mathrm{~N}$ than seagrass. Therefore, seagrass is not a primary food source for $H$. uniremis.

\section{Food source for chum salmon fry}

Chum salmon fry sampled in Seldovia Bay primarily fed on harpacticoid copepods, and Harpacticus uni- remis was the most important among harpacticoid copepod species (Fig. 6). This observation is consistent with other observations in southeast Alaska (Landingham 1982) and British Columbia (Healey 1979, D'Amours 1987) where the major dietary composition of chum salmon fry was also $H$. uniremis. Among benthic harpacticoids, Microarthridion littorale was a major species found in the stomachs of chum salmon fry (authors' pers. obs.).

Carbon isotope ratios of chum salmon fry, especially in May of both years, are lower than harpacticoid copepod values (Fig. 5, Table 1). Juvenile chum salmon depend on energy stored in the yolks from winter hatching to emergence from stream gravel in the spring (Neave 1966a, b). Therefore, fry which first appear in the estuary can have isotopic values similar to those of adult salmon, which have more negative ${ }^{13} \mathrm{C}$ values than harpacticoid copepods. The fry population in May was probably composed of younger fish, which still retained isotopic signatures of the eggs, than the population in June, which had had a longer residence time in the estuary where they primarily fed on harpacticoid copepods.

\section{Feedback mechanism}

Our hypothesis that organic matter derived from decomposition of salmon carcasses is seasonally important to estuarine harpacticoid copepods is supported by the data with the modification that copepods utilize Ulva sp. and its epiphytes rather than dissolved and particulate organic matter derived from salmon carcasses and associated bacteria. The $\delta^{15} \mathrm{~N}$ values of Ulva $\mathrm{sp}$. indicate that this alga utilizes nutrients derived from adult salmon carcasses during late summer and fall months, and the influence of the salmon derived nutrients remains through early spring. Gravid females of some harpacticoid copepod species overwinter, and their offspring are released in early spring (Webb \& Parsons 1992). Because food depletion has been experimentally shown to cause slow development and low fecundity in harpacticoids (Lee et al. 1976. Hicks 1979), the food availability during fall and winter can influence the population size of harpacticoid copepods in spring when juvenile salmon appear in the estuary. In Seldovia Bay, benthic and phytal harpacticoid copepods are the major food source of chum salmon fry (Fig. 6). Because harpacticoid copepods utilized by the salmon fry feed on estuarine algae, there is a nutrient link (temporally indirect link) between adult salmon and juvenile salmon.

Decay of macroalgal detritus can also be a major source of nutrients for seagrass (Williams 1984). As a result, the increased macroalgal production could, in 
turn, act as a nutrient trap which enhances seagrass production in an estuary. Because seagrass beds are important nursery locations for juvenile chum salmon, the nutrients derived from adult salmon carcasses could also influence the success of their offspring through increased availability of both food and shelter.

Based on the residence periods and the existence of an alternative nursery area, Healey (1982) concluded that among the 5 species of Pacific salmon, juvenile pink salmon depend least on estuarine resources. However, the length of residence period does not necessarily indicate how important estuarine resources are to future survival of pinks. Pink salmon spend the short, but crucial, first feeding period in an estuary. The mortality rate of juvenile pink salmon during the first $40 \mathrm{~d}$ can be as high as $77 \%$ (Parker 1965, 1968), and pink salmon have the disadvantage of being smaller than chum salmon when they first emerge (Parker 1971). Therefore, food conditions during the short period in an estuary can be very critical for their future survival and could determine the future population size of pink salmon.

The data support the idea that nutrients derived from inbound adult salmon can have a positive influence on outbound juvenile salmon, suggesting a possible feedback mechanism impacting population size. If a returning population is large, there will be more production in the estuary due to the material available from the carcasses, and, thus, a greater food supply and shelter availability for their offspring. With higher growth and survival rates of salmon fry, more adults could return to the same stream in the future. On the other hand, if only a small number of adult salmon come back to a stream, survival rate of offspring could conceivably be lower because of the reduced food and shelter availability.

Acknowledgements. This project was done for the partial fulfillment of the requirements for the master of science degree in marine biology at the University of Alaska Fairbanks for M.F. We give special thanks to Drs Ted Cooney, John Goering, and Susan Henrichs for their constructive comments. Comments and recommendations by anonymous reviewers have improved the manuscript. Funding for this project was provided in part by a Rasmuson Fisheries Center Student Award, Natural Resource Graduate Fellowship, and a grantin-aid from Sigma Xi to M.F. This project was also supported in part by a grant from Exxon Valdez Oil Spill Trustee Council to R.C.H.

\section{LITERATURE CITED}

Barnard DR (1981) Prey relationships between juvenile pink (Oncorhynchus gorbuscha) and chum (O. keta) salmon in Prince William Sound, Alaska. MSc thesis, University of Alaska Fairbanks

Barraclough WE, Robinson D (1972) The fertilization of Great
Central Lake III. Effect on juvenile sockeye salmon. US Fish Wild Serv Fish Bull 70(1):37-48

Brickell DC, Goening JJ (1970) Chemical effects of salmon decomposition on aquatic ecosystems. In: Murphy RS (ed) First International Symposium on Water Pollution Control in Cold Climates. US Government Printing Office, Washington, DC, p 125-138

Bucher W, Hammarstrom L (1994) 1994 Lower Cook Inlet Area annual finfish management. Regional Information Report No. 2A95-06. Alaska State Department of Fish and Game, Commercial Fisheries Management \& Development Division, Anchorage

Coffin RB, Fry B, Wright RT (1989) Carbon isotopic composition of estuarine bacteria. Limnol Oceanogr 34(7): $1305-1310$

Coffin RB, Velinsky DJ, Devereux R, Price WA, Cifuentes LA (1990) Stable isotope analysis of nucleic acids to trace sources of dissolved substrates used by estuarine bacteria. Appl Environ Microbiol 56:2012-2020

Cordell JR (1986) Structure and dynamics of an epibenthic harpacticoid assemblage and the role of predation by juvenile salmon. MSc thesis, University of Washington, Seattle

D'Amours D (1987) Trophic phasing of juvenile chum salmon (Oncorhynchus keta Walbaum) and harpacticoid copepods in the Fraser River estuary, British Columbia. PhD Dissertation, University of British Columbia

DeNiro MJ, Epstein S (1977) Mechanism of carbon isotope fractionation associated with lipid synthesis. Science 197: $261-263$

Donaldson JR (1967) The phosphorus budget of Iliamna Lake, Alaska, as related to the cyclic abundance of sockeye salmon. PhD Dissertation, University of Washington, Seattle

Eguchi H. Kurohagi T, Yoshizumi K, Sasaki S (1954) The experimental fertilization of Lake Sikotsu (preliminary report). Suisan Fukajo Shiken Houkoku 9:161-176

Feller RJ, Kazynski V (1975) Selective predation by juvenile chum salmon (Oncorhynchus keta) on epibenthic prey in Puget Sound. J Fish Res Bd Can 32:1419-1429

Godin JJ (1981) Daily patterns of feeding behavior, daily rations, and diets of juvenile pink salmon (Oncorhynchus gorbuscha) in two marine bays of British Columbia. Can J Fish Aquat Sci 38:10-15

Goering J, Alexander V, Haubenstock N (1990) Seasonal variability of stable carbon and nitrogen isotope ratios of organisms in a North Pacific Bay. Estuar Coast Shelf Sci 30:239-260

Gu $B$, Alexander V (1993) Estimation of $N_{2}$ fixation based on differences in the natural abundance of ${ }^{15} \mathrm{~N}$ among freshwater $\mathrm{N}_{2}$-fixing and non $\mathrm{N}_{2}$-fixing algae. Oecologia 96 : $43-48$

Hall CAS (1967) Migration and metabolism in a temperate stream ecosystem. Ecology 53(4):585-604

Hall MO, Bell SS (1993) Meiofauna on the seagrass Thalassia testudinum: population characteristics of harpacticoid copepods and associations with algal epiphytes. Mar Biol $116: 137-146$

Healey MC (1979) Detritus and juvenile salmon production in the Nanaimo Estuary: I. Production and feeding rates of the juvenile chum salmon (Oncorhynchus keta). J Fish Res Bd Can 36:488-496

Healey MC (1980) The ecology of juvenile salmon in Georgia Strait, British Columbia. In: McNeil WJ, Himsworth DC (eds) Salmonid ecosystems of the North Pacific. Oregon. State University Press, Corvallis, p 203-229

Healey MC (1982) Timing and relative intensity of size selec- 
tive mortality of juvenile chum salmon (Oncorhynchus keta) during early sea life. Can J Fish Aquat Sci 39: 952-957

Hicks GRF (1979) Pattern and strategy in the reproductive cycle of benthic harpacticoid copepods. In: Naylor E, Hartnall RG (eds) Cyclic phenomena in marine plants and animals. Pergamon Press, New York, p 139-147

Hobson KA, Welch HE (1992) Determination of trophic relationships within a high arctic marine food web using $\delta^{13} \mathrm{C}$ and $\delta^{15} N$ analysis. Mar Ecol Prog Ser 84:9-18

Izumi $\mathrm{H}$, Hattori A (1982) Growth and organic production of eelgrass (Zostera marina L) in temperate waters of the Pacific coast of Japan, III: The kinetics of nitrogen uptake. Aquat Bot 12:245-256

Juday C, Rich WH, Kemmerer Gl, Mann A (1932) Limnological studies of Karluk Lake, Alaska 1926-1930. US Fish Wildl Serv Fish Bull 47:415-436

Kline TC, Goering JJ, Mathisen OA, Poe PH, Parker PL (1990) Recycling of elements transported upstream by runs of Pacific salmon: I. $\delta^{15} \mathrm{~N}$ and $\delta^{13} \mathrm{C}$ evidence in Sashin Creek southeastern Alaska. Can J Fish Aquat Sci 47:136-144

Kline TC, Goering JJ, Mathisen OA, Poe PH, Parker PL Scalan RS (1993) Recycling of elements transported upstream by runs of Pacific salmon: II. $\delta^{15} \mathrm{~N}$ and $\delta^{13} \mathrm{C}$ evidence in the Kvichak river watershed, Bristol Bay, southwestern Alaska. Can J Fish Aquat Sci 50:1350-1365

Krokin EM (1968) Influence of the intensity of passage of the Oncorhynchus nerka (Wald) sockeye on the phosphate content of spawning lakes. Fish Res Bd Can Trans Ser 1273

Landingham JH (1982) Feeding ecology of pink and chum salmon fry in the nearshore habitat of Auke Bay, Alaska. MSc thesis, University of Alaska, Juneau

LeBrasseur RJ, McAllister CD, Barraclough WE, Kennedy OD, Manzer J, Robinson DG, Stephens K (1978) Enhancement of sockeye salmon (Oncorhynchus nerka) by lake fertilization in Great Central Lake: summary report. J Fish Res Bd Can 35:1580-1596

Lee JJ, Tietjen JH, Garrison JR (1976) Seasonal switching in the nutritional requirements of Nitocra typica, a harpacticoid copepod from salt marsh aufwuchs communities. Trans Am Microsc Soc 95(4): 628-637

Massa JR (1995) The feeding ecology of chum salmon fry Oncorhynchus keta in Northern Prince William Sound, Alaska. MSc thesis, University of Alaska, Fairbanks

Mathisen OA (1972) Biogenic enrichment of sockeye salmon lakes and stock productivity. Verh Int Ver Limnol 18: $1089-1095$

Michener RH, Schell DM (1994) Stable isotope ratios as tracers in marine aquatic food webs. In: Lajtha $\mathrm{K}$, Michener $\mathrm{RH}$ (eds) Stable isotopes in ecology and environmental science. Blackwell Scientific Publication, Oxford, p 138-157

Miliou H. Moraitou-Apostolopoulou M (1991) Effects of seven diets on the population dynamics of laboratory cultured Tisbe holothuriae Humes (Copepoda, Harpacticoida). Helgol Meeresunters 45:345-356

Morris AW, Mantoura RFC, Bale AJ, Howland RJM (1978) Very low salinity regions of estuaries: important sites for chemical and biological reactions. Nature 274:678-680

Nadelhoffer KJ, Fry B (1994) Nitrogen isotope studies in forest ecosystems. In: Lajtha K, Michener RH (eds) Stable isotopes in ecology and environmental science. Blackwell Scientific Publication, Oxford, p 22-44

Naiman RJ, Sibert JR (1979) Detritus and juvenile salmon production in the Nanaimo Estuary: III. Importance of detrital carbon to the estuarine ecosystem. J Fish Res Bd Can 36: $504-520$
Neave F (1966a) Salmon of the North Pacific, part III. A review of the life history of North Pacific salmon, 6: Chum salmon in British Columbia. Int North Pacif Fish Comm Bull 18:81-85

Neave F (1966b) Salmon of the North Pacific, part III. A review of the life history of North Pacific salmon, 5. Pink salmon in British Columbia. Int North Pacif Fish Comm Bull 18:71-79

Nelson PR (1959) Effects of fertilizing Bare Lake, Alaska, on growth and production of red salmon (O. nerka). US Fish Wildl Serv Fish Bull 60(159):59-86

Nelson PR, Edmondson WT (1955) Limnological effects of fertilizing Bare Lake, Alaska. US Fish Wildl Serv Fish Bull 56(107):415-436

O'Leary MH (1981) Carbon isotope fractionations in plants. Phytochemistry 20:553-567

Parker PL (1964) The biogeochemistry of the stable isotopes of carbon in a marine bay. Geochim Cosmochim Acta 28 $1155-1164$

Parker RR (1965) Estimation of sea mortality rate for the 1961 brood-year pink salmon of the Bella Coola Area, British Columbia. J Fish Res Bd Can 22(6):1523-1554

Parker RR (1968) Marine mortality schedules of pink salmon of the Bella Coola River, Central British Columbia. J Fish Res Bd Can 25(4):757-794

Parker RR (1971) Size selective predation among juvenile salmonid fishes in a British Columbia inlet. J Fish Res Bd Can 28:1503-1510

Pederson MF, Borum J (1993) An annual nitrogen budget for a seagrass Zostera marina population. Mar Ecol Prog Ser 101:169-177

Peterson BJ, Fry B (1987) Stable isotopes in ecosystem studies. Annu Rev Ecol Syst 18:293-320

Rau GH, Sweeney RE, Kaplan IR, Mearns AJ, Young DR (1981) Differences in animal ${ }^{13} \mathrm{C},{ }^{15} \mathrm{~N}$, and $\mathrm{D}$ abundance between a polluted and an unpolluted coastal site: likely indicators of sewage uptake by a marine food web. Estuar Coast Shelf Sci 13:701-707

Rieper-Kirchner M, Hinz K, Biddanda B (1991) Ingestion of microbially-synthesized organic aggregates and egestion of fecal pellets by marine harpacticoid copepods. Kieler Meeresforsch 8:257-263

Robinson DG, Barraclough WE (1978) Population estimates of sockeye salmon (Oncorhynchus nerka) in a fertilized oligotrophic lake. J Fish Res Bd Can 35:851-860

Schwinghamer P, Tan FC, Gordon DCG Jr (1983) Stable carbon isotope studies on the Pecks Cove mudflat ecosystem in the Cumberland Basin, Bay of Fundy. Can J Fish Aquat Sci 40 (Suppl 1):262-272

Short FT, McRoy CP (1984) Nitrogen uptake by leaves and roots of the seagrass Zostera marina L. Bot Mar 27:547-555

Sibert JR (1979) Detritus and juvenile salmon production in the Nanaimo Estuary: II. Meiofauna available as food to juvenile chum salmon (Oncorhynchus keta). J Fish Res Board Can 36:497-503

Stockner JG (1981) Whole-lake fertilization for the enhancement of sockeye salmon (Oncorhynchus nerka) in British Columbia, Canada. Verh Int Ver Limnol 21:293-299

Sugai FS, Burrell DC (1984) Transport of dissolved organic carbon, nutrients, and trace metals from the Wilson and Blossom rivers to Smeaton Bay, southeast Alaska. Can J Fish Aquat Sci 41:180-190

Wada E, Hattori A (1991) Nitrogen in the sea: forms, abundances, and rate processes. CRC Press, Boca Raton

Watson CE, Branton CI, Newman JE (1971) Climatic characteristics of selected Alaskan locations. University of Alaska, Institute of Agricultural Sciences, Technical Bul- 
letin No. 2, Juneau

Webb DG (1991) Effect of predation by juvenile Pacific salmon on marine harpacticoid copepods. I. Comparisons of patterns of copepod mortality with patterns of salmon consumption. Mar Ecol Prog Ser 72:25-36

Webb DG, Parsons TR (1992) Winter-spring recruitment patterns of epiphytic harpacticoid copepods in a temperate-

Editorial responsibility: Charles Peterson (Contributing Editor), Morehead City, North Carolina, USA zone seagrass bed. Mar Ecol Prog Ser 82:151-162

Welch DW, Parsons TR (1993) $\delta^{13} \mathrm{C}-\delta^{15} \mathrm{~N}$ values as indicators of trophic position and competitive overlap for Pacific salmon (Oncorhynchus spp.). Fish Oceanogr 2:11-23

Williams SL (1984) Decomposition of the tropical macroalgae Caulerpa cupressoides (West) C. Agardh: field and laboratory studies. J Exp Mar Biol Ecol 80:109-124

Submitted: May 19, 1997; Accepted: September 5, 1997 Proofs received from author(s): November 4, 1997 